\title{
Bioactivity of bacterial strains isolated from marine biofilms in Hong Kong waters for the induction of larval settlement in the marine polychaete Hydroides elegans
}

\author{
Stanley C. K. Lau ${ }^{1, *}$, Karen K. W. Mak ${ }^{1, * *}$, Feng Chen ${ }^{2}$, Pei-Yuan Qian ${ }^{1}$ \\ ${ }^{1}$ Department of Biology, The Hong Kong University of Science and Technology, Clear Water Bay, Kowloon, Hong Kong, \\ PR China \\ ${ }^{2}$ Center of Marine Biotechnology, University of Maryland, 701 East Pratt Street, Suite 236, Baltimore, Maryland 21202, USA
}

\begin{abstract}
In the present study, 38 bacterial isolates were obtained from a marine biofilm, identified by the comparison of $16 \mathrm{~S}$ rRNA gene sequences, and investigated by laboratory bioassays for their effects on larval settlement of the marine polychaete Hydroides elegans (Haswell). The bacterial isolates belonged to 3 phylogenetic branches: $\gamma$-Proteobacteria (26 isolates), Gram-positive ( 8 isolates) and Cytophaga-Flexibacter-Bacteroides (4 isolates). Most of the isolates were affiliated to the genera Vibrio (7 isolates), Alteromonas (8 isolates) or Pseudoalteromonas (8 isolates), which are in the $\gamma$-Proteobacteria branch. According to their efficacy to induce larval settlement of $H$. elegans in laboratory bioassays, the isolates were categorized as strongly, moderately, and non-inductive for larval settlement. About $42 \%$ of the isolates were categorized as non-inductive and the rest of the isolates contained equal numbers of highly and moderately inductive strains. The results indicated that larval settlement of $H$. elegans could be induced by bacteria in a wide range of taxa. The isolates that induced high and moderate levels of larval settlement belonged to the genus Cytophaga in the Cytophaga-Flexibacter-Bacteroides branch; the genera Bacillus, Brevibacterium, Micrococcus and Staphylococcus in the Gram-positive branch; and the genera Alteromonas, Pseudoalteromonas and Vibrio in the $\gamma$-Proteobacteria branch. Results also showed that isolates affiliating to the same genus might have tremendously different activities for the induction of larval settlement. For example, isolates that were affiliated to the genus Alteromonas or Pseudoalteromonas distributed over the 3 categories of activity for induction of larval settlement.
\end{abstract}

KEY WORDS: Hydroides elegans $\cdot$ Larval settlement · Biofilm · Bacteria $\cdot$ 16S rRNA genes

Resale or republication not permitted without written consent of the publisher

\section{INTRODUCTION}

All surfaces, both animate and inanimate, exposed to the marine environment are under the pressure of colonization by marine organisms. This colonization is referred to as biofouling. The formation of a biofouling

\footnotetext{
*E-mail: bostan@ust.hk

** Present address: Department of Chemistry, The Hong Kong University of Science and Technology, Clear Water Bay, Kowloon, Hong Kong, PR China
}

community is a dynamic and random process (reviewed by Clare et al. 1992). The primary driving force underlying this process is the relative abundance of each kind of foulers in the water column. The commonly observed sequential formation of biofouling communities (i.e. in the order of colonization: dissolved molecules, bacteria, diatoms, and invertebrates) is a consequence of the primary driving force. The secondary driving forces are physical, chemical and behavioral interactions between the foulers. The interactions between surface-associated bacteria and invertebrate larvae that seek suitable surfaces for settle- 
ment (i.e. attachment and metamorphosis) are wellknown examples for the secondary driving force.

Surface-associated bacteria impose important influences over the settlement of many invertebrate larvae. Bacteria may stimulate (e.g. Szewzyk et al. 1991, Leitz \& Wagner 1993, Lau \& Qian 1997, Unabia \& Hadfield 1999), inhibit (e.g. Holmström et al. 1992, Avelin et al. 1993, Maki et al. 1988, Lau \& Qian 2000) or not affect (e.g. Brancato \& Woollacott 1982, Maki et al. 1988, Avelin et al. 1993, Lau \& Qian 1997, 2000, Unabia \& Hadfield 1999) larval settlement, depending on the species of invertebrates and bacteria of concern. Although the presence of surface-associated bacteria is a prerequisite for larval settlement of certain invertebrates, larvae of these invertebrates may respond to individual bacterial isolates to different extents (Kirchman et al. 1982, Mitchell \& Maki 1988, Lau \& Qian 1997, Unabia \& Hadfield 1999). Previous studies have suggested the effect of surface-associated bacterial communities on larval settlement to be a function of bacterial species composition (Keough \& Raimondi 1996, Lau \& Qian 1997, Rodriguez \& Epifanio 2000). For example, invertebrate larvae settled at different rates in the field when exposed to surfaces that differed in the composition of microbial community (Keough \& Raimondi 1996), and larvae of the mud crab Panopeus herbstii were induced to settle in laboratory conditions only by bacterial communities originated from sediments in the habitat of adult crabs (Rodriguez \& Epifanio 2000)

The paramount importance of surface-associated bacteria for larval settlement of invertebrates makes finding the identity of these bacteria an interesting and important research goal. Larval settlement of the tubeworm Hydroides elegans is induced by surfaceassociated bacteria, but only few bacterial strains appeared to be inductive in laboratory bioassays (Lau \& Qian 1997, Unabia \& Hadfield 1999). Moreover, the species composition of artificially formed bacterial communities has been suggested to be an important factor governing their activity for the induction of larval settlement in $H$. elegans (Lau \& Qian 1997). At present, virtually no information exists on the type(s) of bacteria that induce(s) larval settlement of H. elegans.

In the present study, through the isolation and genetic characterization of bacteria, we investigated the species diversity of bacteria occurring in the habitat of Hydroides elegans in Hong Kong waters. Subsequently, the bacterial isolates were investigated for their efficacies on the induction of larval settlement in $H$. elegans. Our aim was to answer the questions: (1) what are the species of bacteria that induce larval settlement of $H$. elegans?; and, (2) is the settlement induction activity limited to certain taxa of bacteria?

\section{MATERIALS AND METHODS}

Obtaining natural biofilms. Marine biofilms (i.e. conglomerate of organic molecules, bacteria, diatoms and fungi) were collected from the habitat of adult Hydroides elegans, according to the methods stated in Lau \& Qian (1997) with modifications. We opted for the pier of the Hong Kong University of Science and Technology (HKUST), Clear Water Bay, as the collection site at which colonies of $H$. elegans are present year round (Lau \& Qian unpubl. data). Briefly, 5 acidwashed, autoclaved glass microscope slides were submerged in the seawater for the formation of biofilms. The slides were maintained at $2 \mathrm{~m}$ below the lowest water level for the subsequent submersion period. After $3 \mathrm{~d}$, the slides were retrieved, individually encased in $50 \mathrm{ml}$ centrifuge tubes filled with autoclaved, $0.45 \mu \mathrm{m}$ filtered seawater (FSW) and transported to the laboratory immediately. To protect the slides from temperature fluctuation during transportation, the centrifuge tubes were held in a container of seawater collected on site.

Isolation of bacterial strains. In the laboratory, the glass slides were thoroughly rinsed with autoclaved FSW and scraped with an autoclaved nylon paintbrush. The biofilm detached from each slide was individually suspended in $40 \mathrm{ml}$ of autoclaved FSW, mixed vigorously by vortexing and diluted 10 and 100 times in autoclaved FSW. From each biofilm suspension, $200 \mu \mathrm{l}$ aliquots were spread on plates of nutrient agar for bacterial growth $(0.3 \%$ yeast extract, $0.5 \%$ peptone, $1.5 \%$ agar, FSW) in triplicate. The inoculated agar plates were incubated at $30^{\circ} \mathrm{C}$ on a $15: 9 \mathrm{~h}$ light: dark cycle for $24 \mathrm{~h}$. All subsequent incubations for bacterial growth were performed under the same conditions.

The bacterial colonies that grew on the agar plates were examined under a dissecting microscope for morphological characteristics such as color, shape, size, surface topography and the presence of granules. Conspicuous colony types were isolated, purified, and further examined for cellular morphology and growth form in nutrient broth $(0.3 \%$ yeast extract, $0.5 \%$ peptone, FSW). The cell shape and Gram-stain property of the isolates were examined under a light microscope after the procedures for Gram stain (Murray et al. 1994). The isolates' growth form in nutrient broth was examined after growing pure cultures of isolates to stationary phase in nutrient broth in a static condition (i.e. no agitation or aeration). The motility of the isolates in wet-mount was examined under a light microscope. To establish stock cultures, the isolates were grown to the stationary phase in nutrient broth, mixed with equal volume of autoclaved glycerol and stored at $-80^{\circ} \mathrm{C}$ in $1 \mathrm{ml}$ aliquots. 
Table 1. Primers used in this study. The primers are universal for the domain Bacteria. This primer pair amplifies the region between the 27th and 784th nucleotides (Escheria coli numbering) of the 16S rRNA gene

\begin{tabular}{|lcll|}
\hline $\begin{array}{l}\text { Primer } \\
\text { numbering }\end{array}$ & Sequence & Source \\
\hline $26 \mathrm{~F}$ & $8-26$ & 5'-AGAGTTTGATCCTGGCTCA-3' $^{\prime}$ & Hicks et al. (1992) \\
$785 \mathrm{R}$ & $785-804$ & 5'-CTACCAGGGTATCTAATCC-3' $^{\text {Lee et al. (1993) }}$ \\
\hline
\end{tabular}

the accession numbers AF343922 to AF343959.

Phylogenetic assignment. The rDNA sequence of each isolate was compared to the DNA sequences in the non-redundant nucleotide database in GenBank using BLAST (Basic Local Alignment Search Tool).

Larval culture. Adult Hydroides elegans were obtained from a laboratory

Extracting DNA from the isolates. For each isolate, a loopful of pure colony grown on agar plate was suspended in $1 \mathrm{ml}$ of autoclaved double-distilled water $\left(\mathrm{ddH}_{2} \mathrm{O}\right)$, boiled for 15 min (Valsecchi 1998) and centrifuged at $5000 \times g$ for $2 \mathrm{~min}$. While the pellets were discarded, the supernatants were saved as crude DNA extracts and stored at $-20^{\circ} \mathrm{C}$ until use.

PCR amplification of $16 \mathrm{~S}$ rRNA gene. The crude DNA extracts were subject to PCR for the amplification of 16S rRNA gene (rDNA). The primers used in the PCR were 26F and 785R (Table 1), which are specific for the domain Bacteria. Each PCR mixture contained $1 \mathrm{U}$ of AmpliTaq Gold ${ }^{\mathrm{TM}}$ DNA polymerase (Applied Biosystems, USA), GeneAmp ${ }^{\circledR}$ PCR buffer (Applied Biosystems), $1.5 \mathrm{mM} \mathrm{MgCl} 2,0.8 \mu \mathrm{M}$ of each primer, $250 \mathrm{mM}$ of each deoxyribonucleotide triphosphate (dATP, dCTP, dGTP and dTTP) (Pharmacia Biotechnology, USA) and $1 \mu \mathrm{l}$ of crude DNA extract in a total volume of $25 \mu \mathrm{l}$. PCR was performed on a PTC-100 ${ }^{\mathrm{TM}}$ programmable thermal controller with a heated lid (MJ Research, USA) under the following conditions: $95^{\circ} \mathrm{C}$ for $3 \mathrm{~min} ; 35$ cycles of $95^{\circ} \mathrm{C}$ for $1 \mathrm{~min}, 55^{\circ} \mathrm{C}$ for $1 \mathrm{~min}$ and $72^{\circ} \mathrm{C}$ for $1 \mathrm{~min}$; and a final PCR at $72^{\circ} \mathrm{C}$ for $1 \mathrm{~min}$. Subsequently, $7 \mu$ l of each PCR product was subject to electrophoresis performed in a $2 \%$ agarose gel in $1 \times$ Tris-borate-EDTA (TBE) buffer. PCR products on the gel were visualized with UV illumination after staining with ethidium bromide.

Purification and quantification of PCR products. Desired PCR products were subject to purification using Wizard ${ }^{\circledR}$ PCR preps DNA purification system (Promega, USA), according to the manufacturer's instructions. The quantity of DNA in the purified PCR products was determined by using a PicoGreen ${ }^{\circledR}$ doublestranded DNA quantitation kit (Molecular Probes, USA), according to the manufacturer's instructions.

Sequencing of rDNA fragments. The purified PCR amplicons were sequenced bidirectionally using an ABI PRISM ${ }^{\mathrm{TM}}$ big-dye terminator cycle-sequencing ready-reaction kit (Applied Biosystems) and the primer pair mentioned above. The products were resolved on an ABI PRISM ${ }^{\mathrm{TM}} 310$ genetic analyzer (Applied Biosystems), according to the manufacturer's instructions.

Nucleotide sequence accession numbers. Obtained rDNA sequences were submitted to GenBank under brood stock. The procedures for obtaining gametes and raising larvae followed those in Lau \& Qian (1997). Briefly, adult $H$. elegans were placed in a Petri dish containing FSW and stimulated to release gametes by gently probing the anterior ends of the worms with a needle. Newly released oocytes and sperm were mixed and transferred to $500 \mathrm{ml}$ of FSW for fertilization and hatching. After hatching, the larvae were transferred to 21 of FSW and fed with the chrysophyte Isochrysis galbana (Tahitian strain) at a concentration of approximately $6 \times 10^{5}$ cells $\mathrm{ml}^{-1}$. The culture was aerated and maintained at $25^{\circ} \mathrm{C}$ on a $15: 9 \mathrm{~h}$ light:dark cycle. Larvae became competent for settlement after 4 to $5 \mathrm{~d}$ of culture. The larval competency was checked according to the morphological characteristics described in Wisely (1958) and a rapid test with 3-isobutyl-1-methylxanthine (IBMX) according to the methods in Qian \& Pechenik (1998). When over $90 \%$ of the larvae in a culture were competent, the culture was gently filtered through a $90 \mu \mathrm{m}$ nylon mesh to harvest the larvae. Those retained on the mesh were immediately transferred into autoclaved FSW and then, within $5 \mathrm{~min}$, to test vessels for larval settlement bioassays.

Formation of bacterial films for larval settlement bioassays. The effects of bacterial isolates on larval settlement of Hydroides elegans were investigated by bioassays performed in polystyrene Petri dishes (Falcon \#1006) containing monospecies bacterial films. The formation of bacterial films followed the procedures stated in Lau \& Qian (1997) with modifications. Briefly, the isolates were grown to stationary phase in nutrient broth and harvested by centrifugation $(3000 \times g)$. The cell pellets were washed and suspended in autoclaved FSW. The density of bacterial cells in suspension was adjusted to $10^{8}$ cells $\mathrm{ml}^{-1}$ by turbidimetry. From each bacterial suspension, $4 \mathrm{ml}$ aliquots were transferred into pre-sterile Petri dishes and incubated at room temperature for $3 \mathrm{~h}$ to allow the bacteria to attach onto the dish surface. After incubation, Petri dishes were emptied and dipped 10 times into $500 \mathrm{ml}$ of autoclaved FSW to remove unattached cells.

Larval settlement bioassays. The bacterial isolates were arbitrarily distributed over 5 individual bioassays, each performed in 3 repeats. There were 2 sets of controls in each bioassay: (1) Petri dishes without 


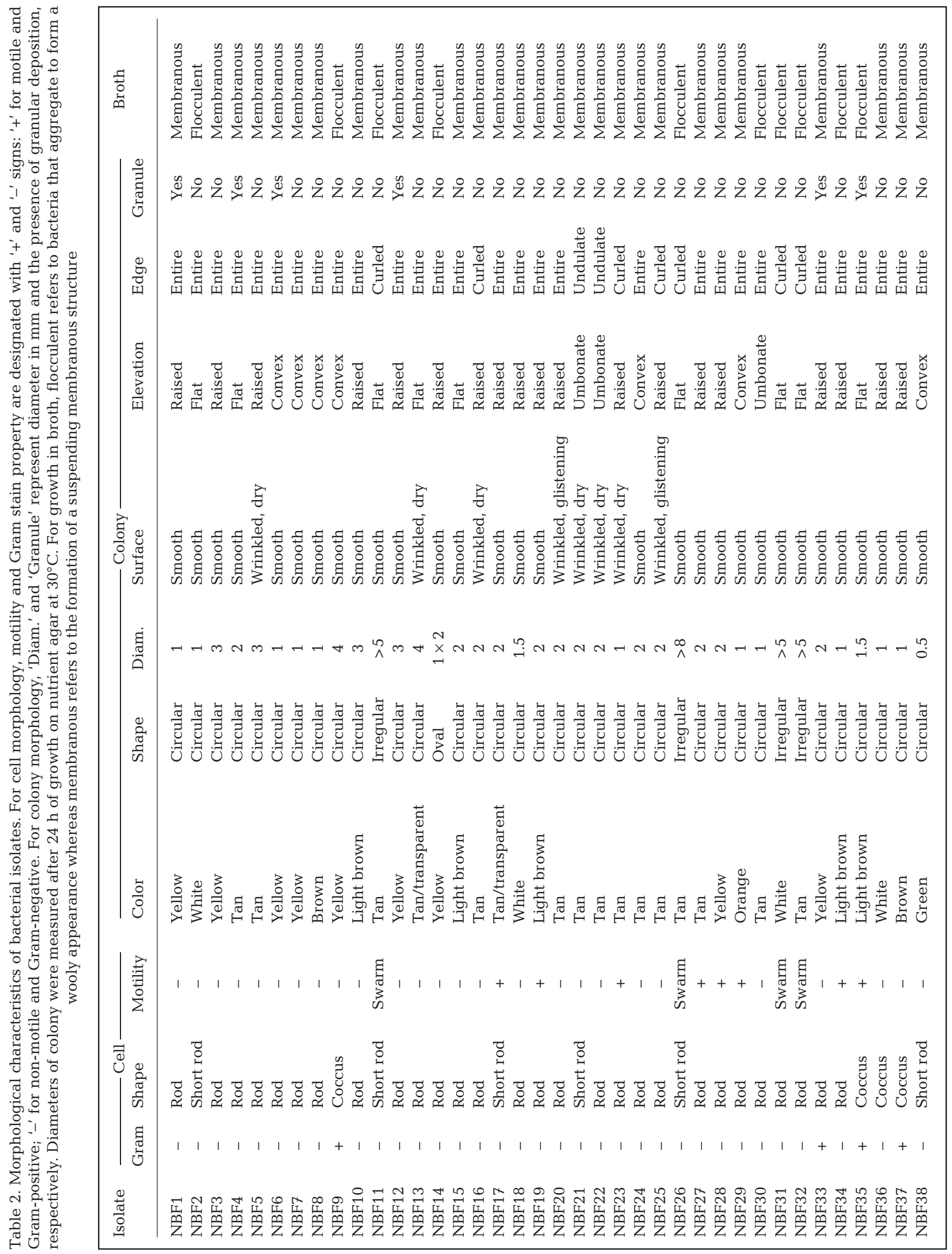


bacterial films; and (2) Petri dishes that were coated with a $3 \mathrm{~d}$ old natural biofilm after submersion at $2 \mathrm{~m}$ depth at HKUST pier. For each treatment 5 replicate dishes, each receiving 20 competent larvae and $4.5 \mathrm{ml}$ of autoclaved FSW, were used. All the dishes were incubated at $25^{\circ} \mathrm{C}$ on a 15:9 h light:dark cycle for $24 \mathrm{~h}$ and the number of settled individuals was recorded after incubation. Individuals that attached on the dish surface, and developed branchial radioles and calcareous tubes were recorded as settled. Mortality and abnormality of larvae were also recorded.

Statistical analysis. Data in the form of percentage of larval settlement were arcsine-transformed prior to statistical analysis. To improve the transformation, a value of $1 / 4 \mathrm{n}$ ( $\mathrm{n}=$ number of larvae used in a replicate) was given to the replicates in which no larvae settled (Zar 1996). The normality of the data was checked with Shapiro-Wilk's test (Shapiro \& Wilk 1965). Data that met the normality assumption of parametric tests were analyzed using 1-way ANOVA followed by Dunnett's test. Those that did not meet the normality assumption were analyzed using non-parametric statistics. This was done by transforming the values to ranks and then applying the above-mentioned statistics (Conover \& Iman 1981). Type 1 rank transformation was used, by which the entire set of data was ranked from the smallest to the largest, with the smallest value having Rank 1, the second smallest having Rank 2, and so on; average ranks were assigned in the event of ties in the ranking (Conover \& Iman 1981). The data presented in all the figures are not transformed.

\section{RESULTS}

\section{Morphological characteristics of bacteria isolated from natural biofilms}

Thirty-eight bacterial morphotypes were isolated from natural biofilms (Table 2). In terms of cell morphology, the bacterial isolates were dominated by Gram-negative rods. Only 4 isolates showed a positive result in Gram stain; 3 were cocci and 1 was rod. Twenty-six isolates appeared to be non-motile and 12 isolates appeared to be motile (including 4 swarming isolates). In terms of colony morphology, tan colored circular colonies were the dominant type (Table 2). Brownish and yellowish colonies were also common. Most of the isolates formed colonies with smooth surfaces; only few had wrinkled surfaces. Some isolates formed colonies with granular depositions. In terms of growth form in nutrient broth without aeration or agitation, 28 isolates showed membranous aggregation while the rest were flocculent.

\section{Identification of bacterial isolates by comparisons of rDNA sequences}

The PCR products obtained with the primers $26 \mathrm{~F}$ and 785R were approximately $800 \mathrm{bp}$, spanning from the 8th to the 804th nucleotide (Escheria coli numbering). Comparison of the 16S rDNA sequences of the isolates to the DNA sequences in the EMBL/GenBank database is given in Table 3. Three isolates were affiliated to some unidentified strains; 35 isolates were affiliated to the 9 genera, including Alteromonas (8 isolates), Pseudoalteromonas (8 isolates), Pseudomonas (1 isolate), Vibrio (7 isolates), Bacillus (2 isolates), Brevibacterium (1 isolate), Micrococcus (2 isolates), Staphylococcus (2 isolates) and Cytophaga (4 isolates). These genera distribute over 3 phylogenetic branches: $\gamma$-Proteobacteria, Gram-positive and Cytophaga-Flexibacter-Bacteroides.

\section{Effect of the isolates on larval settlement}

All bacterial strains formed films that were visible under a low-power dissection microscope and all films appeared to be confluent. In all bioassays, natural biofilms (positive control) elicited the highest amount of larval settlement in Hydroides elegans (30 to $70 \%$ ) and clean surface (negative control) had the lowest (0 to $25 \%$ ) (Fig. 1a to e). In all bioassays, the amounts of larval settlement on the films of individual isolates spanned between the 2 controls (Fig. 1a to e). Since the isolates induced highly variable amounts of larval settlement in different experimental repeats (e.g. isolates NBF1, 5 and 8 in Fig. 1a), the larval settlement inductive effect of each bacterial isolate was determined according to the summation of results from 3 repeats and was categorized as having strong, moderate or no activity for the induction of larval settlement (Fig. 2, Table 4). Strongly inductive isolates were the ones that had percentages of larval settlement equal to or higher than natural biofilm $(\alpha=0.05$, Dunnett's test) in at least 2 of the 3 trials. Non-inductive isolates are the ones that had percentages of larval settlement equal to or less than a clean surface $(\alpha=0.05$, Dunnett's test) in at least 2 of the 3 trials. Isolates that do not fall into these 2 categories were classified as moderately inductive. Under these criteria, $58 \%$ of the isolates were categorized as strongly or moderately inductive, and the remaining $42 \%$ of isolates were classified as having no effect on larval settlement.

\section{DISCUSSION}

Microbial diversity often appears to be overwhelming, as demonstrated by the occurrence of several thou- 
sand independent bacterial genomes in 1 soil sample (Torsvik et al. 1990). However, in many ecosystems, bacterial numbers estimated by counts of colony forming units (CFU) are orders of magnitude lower than those by epiflourescence direct counts (Hobbie et al. 1977, Kogure et al. 1979). Although a large portion of cells detected by direct counts on natural samples is empty, referred to as 'ghost cells' (Zweifel \& Hagström 1995, Heissenberger et al. 1996, Karner \& Fuhrman 1997, Vosjan \& van Noort 1998), culturable bacteria normally represent less than $1 \%$ of living bacteria extant in the environment (Pace 1996). This discrepancy is referred to as the great plate count anomaly (Staley \& Konopka 1985). The current dogma in microbial ecology is that culturable bacteria are not the representatives of bacteria extant in the environment.

During the last decade, culture independent methods have emerged to describe the microbial diversity in different environments (Olsen et al. 1986). This has mainly been done by extracting and analyzing community

Table 3. Phylogenetic affiliation of bacterial isolates. The 16S rRNA gene sequences of individual bacterial isolates were compared to the nucleotide sequences in GenBank. The closest matching nucleotide sequence for each bacterial isolate is indicated by the strain name and accession number. 'Larval settlement' indicates the activity for the induction of larval settlement in Hydroides elegans (refer to Table 4 for details)

\begin{tabular}{|c|c|c|c|c|}
\hline \multirow[t]{2}{*}{ Isolate } & \multicolumn{3}{|c|}{ C Closest match at GenBank — } & \multirow{2}{*}{$\begin{array}{l}\text { Larval } \\
\text { settlemen }\end{array}$} \\
\hline & Strain & Genbank accession number & Sequence similarity (\%) & \\
\hline \multicolumn{5}{|c|}{$\gamma$-Proteobacteria division } \\
\hline NBF13 & Uncultured DCM-ATT-24 & AF114598 & 94 & Moderate \\
\hline NBF22 & $\begin{array}{l}\text { Uncultured } \gamma \text {-Proteobacterium } \\
\text { Isolate } 400 \mathrm{M} \text { ATT }\end{array}$ & AF114495 & 98 & None \\
\hline NBF19 & Alteromonas sp. & AB015135 & 95 & Moderate \\
\hline NBF21 & Alteromonas sp. SCB33 & U64010 & 93 & Strong \\
\hline NBF16 & Alteromonas macleodii DSM 6062 & Y18228 & 99 & Moderate \\
\hline NBF17 & Alteromonas macleodii DSM 6062 & Y18228 & 99 & Moderate \\
\hline NBF18 & Alteromonas macleodii DSM 6062 & Y18228 & 98 & Strong \\
\hline NBF20 & Alteromonas macleodii DSM 6062 & Y18228 & 97 & Moderate \\
\hline NBF34 & Alteromonas macleodii & AF025957 & 95 & Strong \\
\hline NBF38 & Alteromonas macleodii & AF025957 & 97 & None \\
\hline NBF5 & Pseudoalteromonas sp. Isolate PRLIST2 & Y15323 & 99 & Moderate \\
\hline NBF3 & Pseudoalteromonas sp. Strain S9 & U80834 & 98 & Moderate \\
\hline NBF8 & Pseudoalteromonas sp. Strain S9 & U80834 & 97 & Moderate \\
\hline NBF11 & Pseudoalteromonas sp. Strain S9 & U80834 & 96 & None \\
\hline NBF15 & Pseudoalteromonas sp. Strain S9 & U80834 & 99 & Strong \\
\hline NBF24 & Pseudoalteromonas sp. Strain S9 & U80834 & 98 & None \\
\hline NBF25 & Pseudoalteromonas sp. Strain S9 & U80834 & 99 & None \\
\hline NBF28 & Pseudoalteromonas piscicida & AF297959 & 97 & Strong \\
\hline NBF23 & Pseudomonas stutzeri DNSP21 & U26414 & 99 & None \\
\hline NBF26 & Uncultured Vibrio & AF108137 & 96 & Strong \\
\hline NBF31 & Vibrio strain NAP-4 & $\mathrm{AF} 064637$ & 97 & None \\
\hline NBF10 & Vibrio alginolyticus ATCC 17749T & X74690 & 97 & Strong \\
\hline NBF32 & Vibrio haloticoli IAM14599 & AB000393 & 91 & None \\
\hline NBF4 & Vibrio mediterranei CIP 103203T & $\mathrm{X} 74710$ & 97 & None \\
\hline NBF2 & Vibrio nigripulchritudo ATCC $27043 \mathrm{~T}$ & $\mathrm{X} 74717$ & 94 & None \\
\hline NBF27 & Vibrio tubiashi ATCC 19109T & X74725 & 100 & Strong \\
\hline \multicolumn{5}{|c|}{ Gram-positive division } \\
\hline NBF29 & Benzene mineralizing bacterium & AF029046 & 97 & None \\
\hline NBF1 & Bacillus halmapalus DSM 8723 & $\mathrm{X} 76447$ & 97 & Moderate \\
\hline NBF33 & Bacillus halmapalus DSM 8723 & X76447 & 97 & None \\
\hline NBF30 & Brevibacterium casei NCDO 2048 & X76564 & 96 & Moderate \\
\hline NBF9 & Micrococcus luteus & AB023371 & 98 & None \\
\hline NBF35 & Micrococcus luteus & AF057289 & 96 & Strong \\
\hline NBF36 & Staphylococcus haemolyticus & L37600 & 97 & Strong \\
\hline NBF37 & Staphylococcus aureus ATCC $12600 \mathrm{~T}$ & D83358 & 99 & None \\
\hline \multicolumn{5}{|c|}{ Cytophaga-Flexibacter-Bacteroides division } \\
\hline NBF6 & Cytophaga sp. F12 & AF125325 & 90 & Strong \\
\hline NBF7 & Cytophaga sp. F12 & AF125325 & 93 & None \\
\hline NBF12 & Cytophaga sp. F12 & AF125325 & 93 & None \\
\hline NBF14 & Cytophaga sp. F12 & AF125325 & 92 & Moderate \\
\hline
\end{tabular}


a

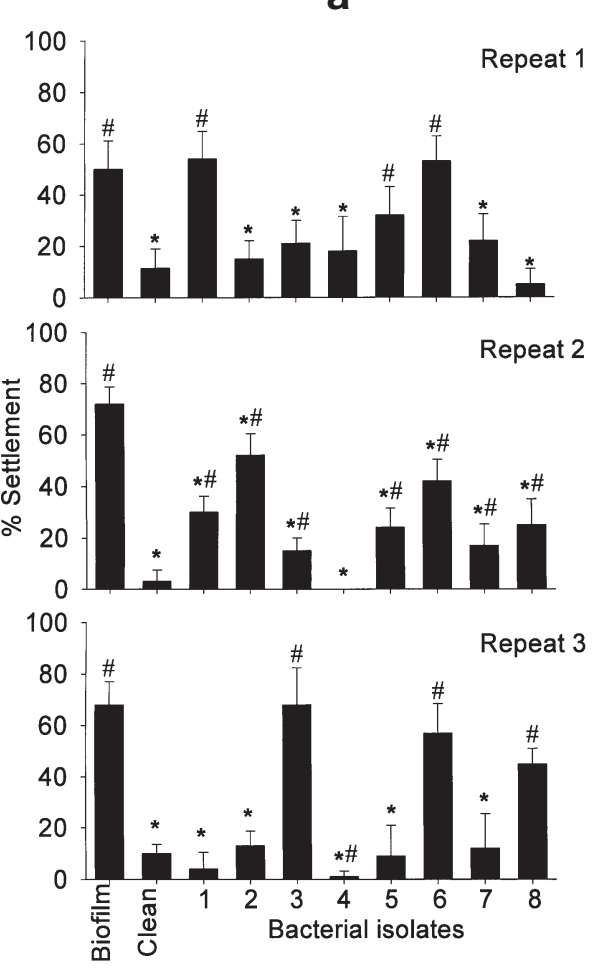

b

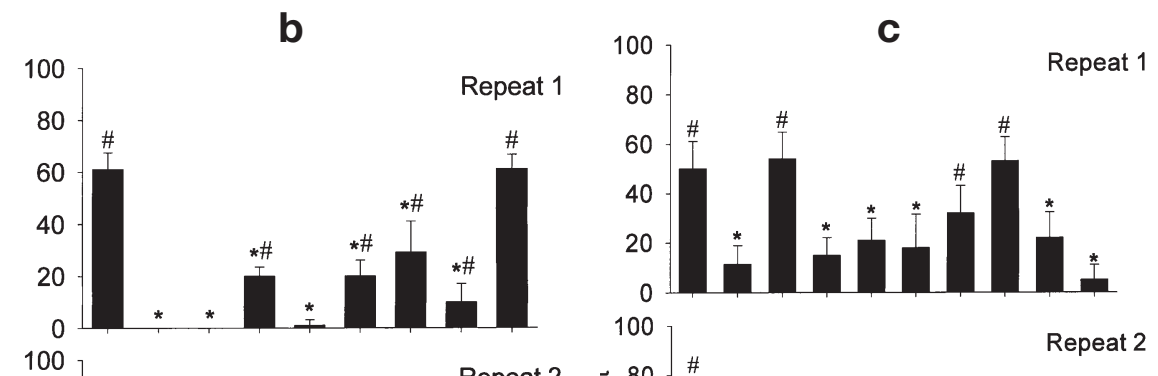

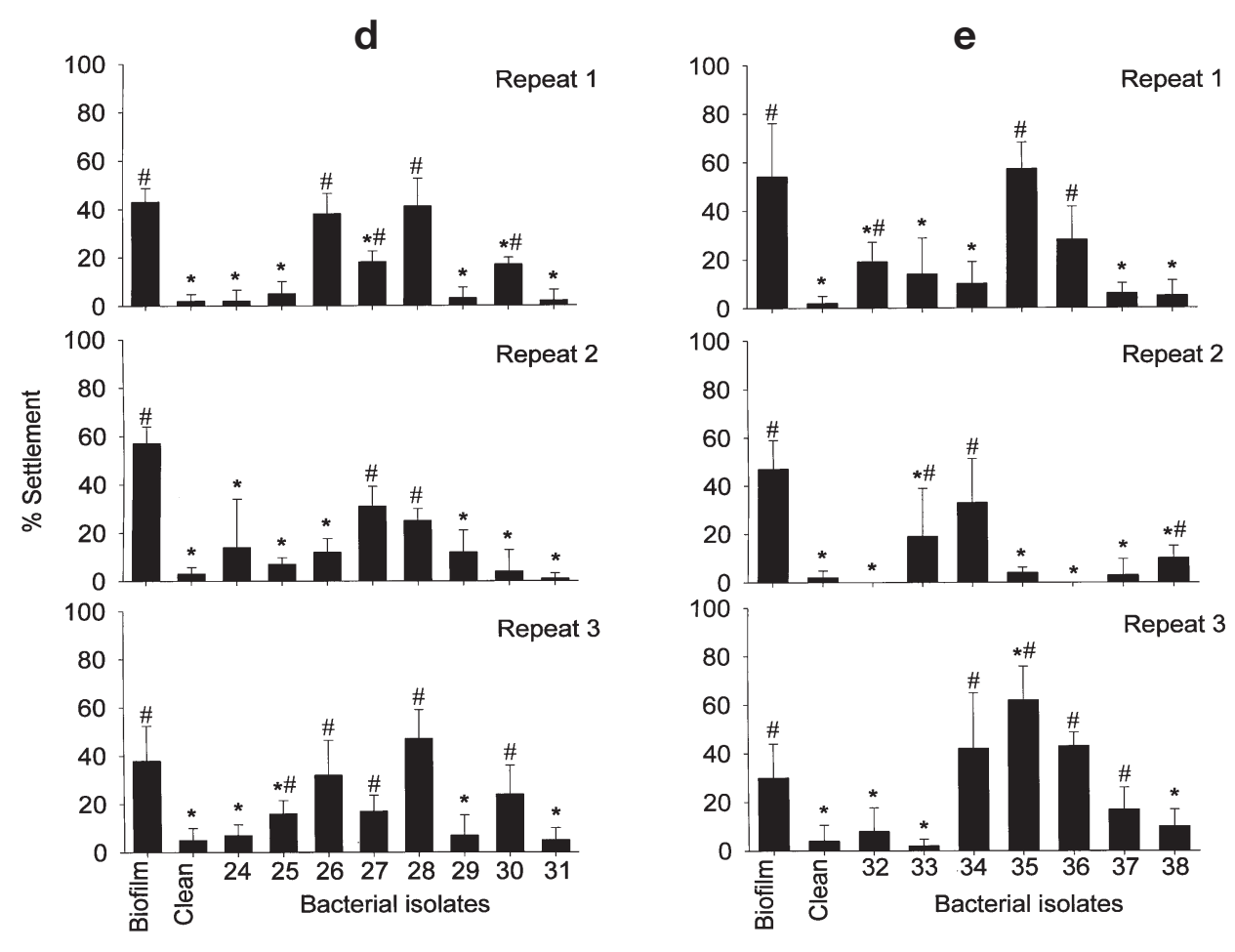

Fig. 1. Hydroides elegans. Larval settlement in response to the bacterial isolates after $24 \mathrm{~h}$ of incubation. The bacterial isolates were arbitrarily distributed over 5 individual bioassays (a-e), each performed in triplicate (denoted as Repeats 1, 2 and 3). The numbers on the $x$-axis indicate individual bacterial isolates: 1 for isolate NBF1, 2 for isolate NBF2, and so on. Control dishes containing $3 \mathrm{~d}$ old natural biofilms and control dishes with clean surfaces are indicated as Biofilm and Clean, respectively. Data are expressed as mean $\pm 1 \mathrm{SD}$ of 5 replicates. Data that are significantly different from natural biofilm at $\alpha=0.05$ in Dunnett's test are indicated by* whereas data that are significantly different from clean surface at $\alpha=0.05$ in Dunnett's test are indicated by \# 


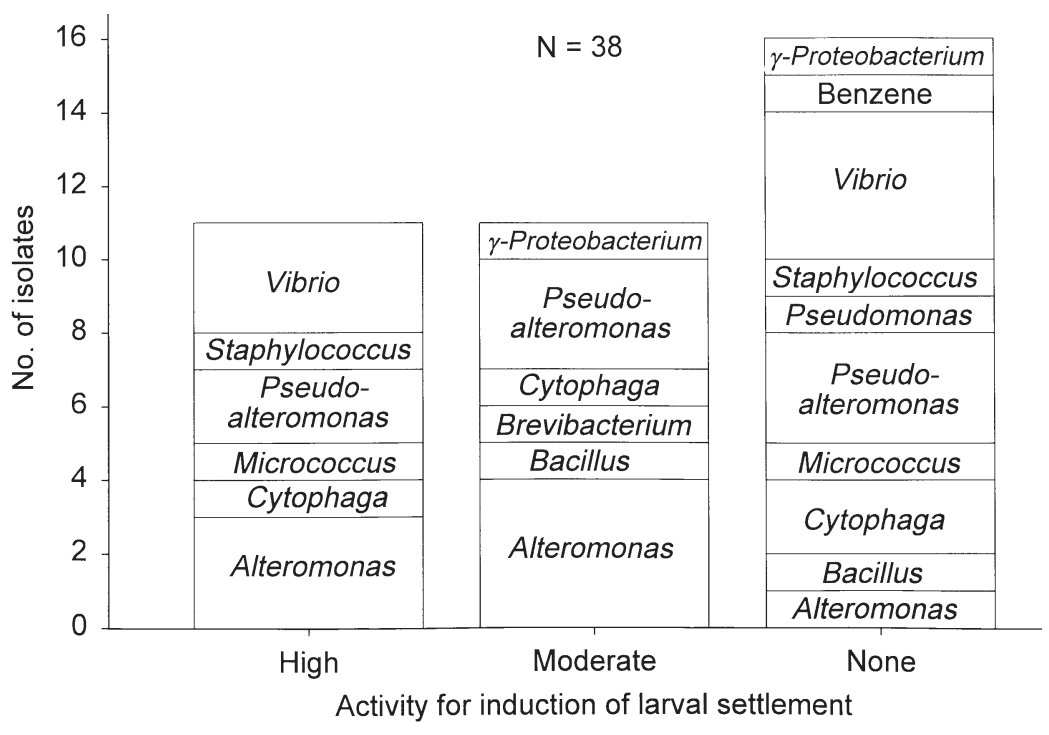

Fig. 2. A summary for Tables $3 \& 4$. Information shown is the number of bacterial isolates being assigned to each category of settlement induction activity. The isolates in each category are grouped into the genera that the isolates were affiliated

rDNA sequences from environmental samples, and has revealed a profound diversity of microbes not described previously (Giovannoni et al. 1990, Amann et al. 1991, Fuhrman et al. 1994). Although the culture-dependent method has long been known to underestimate bacterial diversity in natural samples, it was taken as an important approach in this study. Since the investigation of larval settlement induction activity of bacteria requires the bacteria to be cultured for bioassays, the direct analysis of community rDNA for bacterial diversity does not fulfill the need of this study. On the other hand, there has been emerging evidence showing that, in contrast to other ecosystems, the marine environment may host a higher proportion of culturable bacteria (Rehnstam et al. 1993, Fuhrman et al. 1994). Therefore, culture-dependent analysis of microbial diversity in marine samples may be more meaningful than for samples from other ecosystems.

The results of this study revealed that the culturable bacterial portion in natural biofilms was low in diversity with most of the isolates belonging to the genera Alteromonas, Pseudoalteromonas and Vibrio in the $\gamma$-Proteobacteria branch (Table 3). Previous studies have shown by the analysis of community rDNA sequences that bacterial community in the aquatic environment is markedly different for cells that are free living and those associated with substratum. While the free-living bacterial compartment is dominated by members of $\alpha$-Proteobacteria, the attached bacterial community is mainly composed of strains in $\gamma$-Proteobacteria branch (DeLong et al. 1993, Acinas et al. 1999). On a global scale, Alteromonas, Pseudoalteromonas and Vibrio are the dominant genera in attached bacterial communities (see Pinhassi et al. 1997 for a review).

Comparison of $16 \mathrm{~S}$ rRNA showed that 8 isolates belonged to the Gram-positive branch (Table 3), but some of these isolates appeared to be negative in Gram stain, for example isolates NBF1 (Bacillus), NBF30 (Brevibacterium) and NBF36 (Staphylococcus) (Table 2). The discrepancy may be due to over-decolorizing in the destaining process. Brevibacterium is known to be prone to decolorization in Gram stain (Holt et al. 1984). In addition, some Bacillus strains might give a positive result in Gram stain only when in early stage of growth and some Bacillus strains may never appear to be Gram-positive (Holt et al. 1984).

For the induction of larval settlement, the isolates in this study exhibited highly variable activities (Fig. 1). The isolates were categorized as strongly, moderately, and noninductive for larval settlement by comparing the amounts of larval settlement occurring on the films of individual bacterial isolates to those on natural biofilms and clean surfaces, respectively (Fig. 2). Under these criteria, $42 \%$ of the isolates belonged to the non-inductive category and the rest of the isolates contained equal numbers of highly and moderately inductive strains (Fig. 2). Our results are similar to those by Unabia \& Hadfield (1999), who isolated 34 bacterial strains from biofilms developed in Hawaiian waters and showed that only a small portion of the isolates was as active as natural biofilms in terms of induction of larval settlement in Hydroides elegans. In addition, Lau \& Qian (1997) suggested that the larval settlement inductive effect of a bacterial community could be due to a small portion of settlement-inductive bacteria present in the community.

Results here revealed that larval settlement of Hydroides elegans could be induced by a variety of bacteria belonging to the genus Cytophaga in the Cytophaga-Flexibacter-Bacteroides branch; the genera Bacillus, Brevibacterium, Micrococcus and Staphylococcus in the Gram-positive branch; and the genera Alteromonas, Pseudoalteromonas and Vibrio in the $\gamma$-Proteobacteria branch (Fig. 2). Results also showed that isolates that were affiliated to the same genus had different activities for the induction of larval settlement (Fig. 2). For the $\gamma-$ Proteobacteria branch, isolates that belong to the genus Alteromonas or Pseudoalteromonas distributed all over the 3 categories of activity for induction of larval settlement; isolates belonging to Vibrio were either strongly or non-inductive for larval settlement. Isolates belonging to the Gram-positive or the Cytophaga-Flexibacter-Bacteroides branch also distributed across the 3 categories. 
In many studies, the effects of individual bacterial strains on larval settlement have varied tremendously among trials (for example, isolates NBF1 and 24 in the

Table 4. The bacterial isolates' activity for the induction of larval settlement in Hydroides elegans. Data shown are the number of repeats in which individual isolates induced a particular level of larval settlement. The isolates were categorized as strongly, moderately and non-inductive for larval settlement. 'Strong' refers to the isolates that were as inductive as natural biofilms ( $\geq$ Biofilm) in at least 2 of the 3 repeats; 'No effect' indicates isolates that were inactive $(\leq$ Clean) in at least 2 of the 3 repeats. Isolates that do not fall into these 2 categories are shown as 'Moderate'

\begin{tabular}{|c|c|c|c|c|}
\hline \multirow{2}{*}{ Isolate } & \multicolumn{3}{|c|}{ No. of repeats } & \multirow{2}{*}{$\begin{array}{l}\text { Induction } \\
\text { of larval } \\
\text { settlement }\end{array}$} \\
\hline & $\geq$ Biofilm $^{\mathrm{a}}$ & $\begin{array}{l}<\text { Biofilm \& } \\
>\text { Clean }^{b}\end{array}$ & $\leq$ Clean $^{\mathrm{c}}$ & \\
\hline NBF1 & 1 & 1 & 1 & Moderate \\
\hline NBF2 & 0 & 1 & 2 & None \\
\hline NBF3 & 1 & 1 & 1 & Moderate \\
\hline NBF4 & 0 & 0 & 3 & None \\
\hline NBF5 & 1 & 1 & 1 & Moderate \\
\hline NBF6 & 2 & 1 & 0 & Strong \\
\hline NBF7 & 0 & 1 & 2 & None \\
\hline NBF8 & 1 & 1 & 1 & Moderate \\
\hline NBF9 & 0 & 0 & 3 & None \\
\hline NBF10 & 2 & 1 & 0 & Strong \\
\hline NBF11 & 1 & 0 & 2 & None \\
\hline NBF12 & 0 & 1 & 2 & None \\
\hline NBF13 & 1 & 1 & 1 & Moderate \\
\hline NBF14 & 0 & 2 & 1 & Moderate \\
\hline NBF15 & 2 & 1 & 0 & Strong \\
\hline NBF16 & 0 & 3 & 0 & Moderate \\
\hline NBF17 & 1 & 1 & 1 & Moderate \\
\hline NBF18 & 2 & 1 & 0 & Strong \\
\hline NBF19 & 1 & 1 & 1 & Moderate \\
\hline NBF20 & 0 & 3 & 0 & Moderate \\
\hline NBF21 & 2 & 1 & 0 & Strong \\
\hline NBF22 & 0 & 0 & 3 & None \\
\hline NBF23 & 1 & 0 & 2 & None \\
\hline NBF24 & 0 & 0 & 3 & None \\
\hline NBF25 & 0 & 1 & 2 & None \\
\hline NBF26 & 2 & 0 & 1 & Strong \\
\hline NBF27 & 2 & 1 & 0 & Strong \\
\hline NBF28 & 3 & 0 & 0 & Strong \\
\hline NBF29 & 0 & 0 & 3 & None \\
\hline NBF30 & 1 & 1 & 1 & Moderate \\
\hline NBF31 & 0 & 0 & 3 & None \\
\hline NBF32 & 0 & 1 & 2 & None \\
\hline NBF33 & 0 & 1 & 2 & None \\
\hline NBF34 & 2 & 0 & 1 & Strong \\
\hline NBF35 & 2 & 0 & 1 & Strong \\
\hline NBF36 & 2 & 0 & 1 & Strong \\
\hline NBF37 & 1 & 0 & 2 & None \\
\hline NBF38 & 0 & 1 & 2 & None \\
\hline \multicolumn{5}{|c|}{$\begin{array}{l}\text { aPercentages of larval settlement that are higher than or } \\
\text { equal to those on natural biofilms }\end{array}$} \\
\hline \multicolumn{5}{|c|}{$\begin{array}{l}\text { bercentages of larval settlement that are in-between those } \\
\text { on natural biofilms and clean surfaces }\end{array}$} \\
\hline \multicolumn{5}{|c|}{$\begin{array}{l}\text { 'Percentages of larval settlement that are equal to or lower } \\
\text { than those on clean surfaces }\end{array}$} \\
\hline
\end{tabular}

present study; see also Lau \& Qian 1997, 2000, Unabia \& Hadfield 1999). The cause of this variation is not clear, but the most probable explanation seems to be that there are unavoidable variations in the physiological conditions of the larvae and bacteria that are involved in the bioassays (Wieczorek et al. 1996, Wieczorek \& Todd 1998, Lau \& Qian 2001). Importantly, this variation in larval response towards a bacterial strain revealed a complex and dynamic interaction between larvae and bacteria. The amount of larval settlement on natural biofilms is comparatively consistent. It may be due to the fact that natural biofilms are comprised of bacterial strains that are of different species and physiological status. It was suggested that the settlement of larvae on a biofilm might be to a result of the overall stimuli (facilitation and/or inhibition) from the constituent bacteria (Lau \& Qian 1997, Maki 1999).

In conclusion, the results of our experiments indicate that competent larvae of Hydroides elegans respond to bacteria in a wide range of taxa and that bacterial isolates belonging to the same genus may have tremendously different activities for the induction of larval settlement. Therefore, the settlement response of larvae to bacteria is not likely to be taxon specific. At this point, it is unclear whether this broad range of inductive bacteria produces the same larval settlement cue for $H$. elegans or that different bacteria produce different cues. Resolution of this question awaits the results of ongoing studies on the isolation and characterization of the larval settlement cue.

Acknowledgements. The authors thank 2 anonymous referees for comments on this manuscript. This study was supported by the US NSF grant OCE-9730602 awarded to F.C. and the RGC grant HKUST6133/99M to P.Y.Q.

\section{LITERATURE CITED}

Acinas SG, Anton J, Rodriguez-Valera F (1999) Diversity of free-living and attached bacteria in offshore western Mediterranean waters as depicted by analysis of genes encoding 16 rRNA. Appl Environ Microbiol 65:514-522

Amann R, Springer N, Ludwig W, Gortz, HD, Schleifer KH (1991) Identification in situ and phylogeny of uncultured bacterial endosymbionts. Nature 351:161-164

Avelin M Sr, Vitalina M Sr, Rittschof D, Nagabhushanam R (1993) Bacterial-barnacle interaction: potential of using juncellins and antibiotics to alter structure of bacterial communities. J Chem Ecol 19(10):2155-2167

Brancato MS, Woollacott RM (1982) Effect of microbial films on settlement of bryozoan larave (Bugula simplex, $B$. stolonifera and B. turrita). Mar Biol 71:51-56

Clare AS, Rittschof D, Gerhart DJ, Maki JS (1992) Molecular approaches to nontoxic antifouling. Invertebr Reprod Dev 22(1-3):67-76

Conover WJ, Iman L (1981) Rank transformations as a bridge between parametric and nonparametric statistics. Am Stat 35:124-129

DeLong EF, Franks DG, Alldredge AL (1993) Phylogenetic 
diversity of aggregated-attached vs. free-living marine bacteria assemblages. Limnol Oceanogr 38:924-934

Fuhrman JA, Le SH, Masuchi Y, Davis AA, Wilcox RM (1994) Characterization of marine prokaryotic communities via DNA and RNA. Microb Ecol 28:133-145

Giovannoni SJ, Britschgi TB, Moyer CL, Field KL (1990) Genetic diversity in Sargasso Sea bacterioplankton. Nature 345:60-63

Heissenberger A, Leppard GG, Herndl GJ (1996) Relationship between the intracellular integrity and the morphology of the capsular envelope in attached and free-living marine bacteria. Appl Environ Microbiol 62:4521-4528

Hicks RE, Amann RI, Stahl DA (1992) Dual staining of natural bacterioplankton with 4'6-diamino-2-phenylindole and fluorescent oligonucleotide probes targeting kingdomlevel 16S rRNA sequences. Appl Environ Microbiol 58: 2158-2163

Hobbie JE, Daley RJ, Jasper S (1977) Use of Nucleopore filters for counting bacteria by epifluorescence microscopy. Appl Environ Microbiol 33:1225-1228

Holmström C, Rittschof D, Kjelleberg S (1992) Inhibition of settlement by larvae of Balanus amphritie and Ciona intestinalis by a surface colonizing marine bacterium. Appl Environ Microbiol 58:2111-2115

Holt JG, Staley JT, Byrant MP, Pfenning N (eds) (1984) Bergey's manual of systematic bacteriology, Vols 1-4. Williams \& Wilkins, Baltimore

Karner M, Fuhrman JA (1997) Determination of active marine bacterioplankton: a comparsion of universal 16S rRNA probes, autoradiography, and nucleoid staining. Appl Environ Microbiol 63:1208-1213

Keough MJ, Raimondi PT (1996) Responses of settling invertebrate larvae to bioorganic films: effects of large-scale variation in films. J Exp Mar Biol Ecol 207:59-78

Kirchman D, Graham S, Reish D, Mitchell R (1982) Bacteria induce settlement and metamorphosis of Janua (Dexiospira) brasiliensis Grube (Polychaeta: Spirorbidae). J Exp Mar Biol Ecol 56:153-163

Kogure K, Simidu U, Taga N (1979) A tentative direct microscopic method for counting living marine bacteria. Can J Microbiol 25:415-420

Lau SCK, Qian PY (1997) Phlorotannins and related compounds as larval settlement inhibitors of a tube-building polychaete Hydroides elegans (Haswell). Mar Ecol Prog Ser 159:219-227

Lau SCK, Qian PY (2000) Inhibitory effect of phenolic compounds and marine bacteria on larval settlement of the barnacle Balanus amphitrite amphitrite Darwin. Biofouling 16(1):47-58

Lau SCK, Qian PY (2001) Larval settlement in the serpulid polychaete Hydroides elegans (Haswell) in response to bacterial films: an investigation of the nature of presumptive larval settlement cue. Mar Biol 138:321-328

Lee S, Malone C, Kemp PF (1993) Use of multiple 16S rRNAtargeted fluorescent probes to increase signal strength and measure cellular RNA from natural planktonic bacteria. Mar Ecol Prog Ser 101:193-201

Leitz T, Wagner T (1993) The marine bacterium Alteromonas espejiana induces metamorphosis of the hydroid Hydractinia echinata. Mar Biol 115:173-178

Maki JS (1999) The influence of marine microbes on biofouling. In: Fingerman M, Nagabhushanam R, Thompson M (eds) Recent advances in marine biotechnology. Science Publishers Inc., Enfield, NH, p 147-171

Maki JS, Rittschof D, Costlow JD, Mitchell R (1988) Inhibition of attachment of larval barnacles, Balanus amphitrite, by bacterial surface films. Mar Biol 97:199-206

Mitchell R, Maki JS (1988) Microbial surface films and their influence on larval settlement and metamorphosis in the marine environment. In: Thomspon MF, Sarojini R, Nagabhushanam $\mathrm{R}$ (eds) Advanced techniques applicable to the Indian Ocean. Oxford \& IBH Publishing Company, New Delhi, p 489-497

Murray RGE, Doetsch RN, Robinow CF (1994) Determinative and cytological light microscopy. In: Gerhardt P, Murray RGE, Wood WA, Krieg NR (eds) Methods for general and molecular bacteriology. American Society for Microbiology, Washington, DC, p 21-41

Olsen GJ, Lane DJ, Giovannoni SJ, Pace NR (1986) Microbial ecology and evolution: a ribosomal RNA approach. Annu Rev Microbiol 40:337-265

Pace NR (1996) New prospectives on the natural microbial world: molecular microbial ecology. ASM News 62:463-470

Pinhassi J, Zweifel UL, Hagström A (1997) Dominant marine bacterioplankton species found among colony-forming bacteria. Appl Environ Microbiol 63(9):3359-3366

Qian PY, Pechenik JA (1998) Effects of larval starvation and delayed metamorphosis on juvenile survival and growth of the tube-dwelling polychaete Hydroides elegans (Haswell). J Exp Mar Biol Ecol 227:169-185

Rehnstam AS, Backman S, Smith DC, Azam F, Hagström A (1993) Blooms of sequence-specific culturable bacteria in the sea. FEMS Microbiol Ecol 102:161-166

Rodriguez RA, Epifanio CE (2000) Multiple cues for induction of metamorphosis in larvae of the common mud crab Panopeus herbstii. Mar Ecol Prog Ser 195:221-229

Shapiro SS, Wilk MB (1965) An analysis of variance test for normality (complete samples). Biometrika 52:591-611

Staley JT, Konopka A (1985) Measurement of in situ activities of nonphotosynthetic microorganisms in aquatic and terrestrial habitats. Annu Rev Microbiol 39:321-346

Szewzyk U, Holmström C, Wrangstadh M, Samuelsson MO, Maki JS, Kjelleberg S (1991) Relevance of the exopolysaccharide of marine Pseudomonas sp. strain S9 for the attachment of Ciona intestinalis larvae. Mar Ecol Prog Ser 75:259-265

Torsvik V, Goksoyr J, Daae FL (1990) High diversity of DNA of soil bacteria. Appl Environ Microbiol 56:782-787

Unabia CRC, Hadfield MG (1999) Role of bacteria in larval settlement and metamorphosis of the polychaete Hydroides elegans. Mar Biol 133:55-64

Valsecchi E (1998) Tissue boiling: a short-cut in DNA extraction for large-scale population screenings. Mol Ecol 7: 1243-1245

Vosjan JH, van Noort GJ (1998) Enumerating nucleoid-visible marine bacterioplankton: bacterial abundance determined after storage of formalin fixed samples agrees with isopropanol rinsing method. Aquat Microb Ecol 14:149-154

Wieczorek SK, Todd CD (1998) Inhibition and facilitation of settlement of epifunal marine invertebrate larvae by microbial biofilm cues. Biofouling 12:81-118

Wieczorek SK, Murray AWA, Todd CD (1996) Seasonal variation in the effects of hard substratum biofilming on settlement of marine invertebrate larvae. Biofouling 10:309-330

Wisely B (1958) The development and settling of a serpulid worm, Hydroides norvegica Gunnerus (Ploychaeta). Aust J Mar Freshw Res 9(3):351-361

Zar JH (1996) Biostatistical analysis, 3rd edn. Prentice-Hall, New York

Zweifel UL, Hagström Å (1995) Total counts of marine bacteria include a large fraction of non-nucleoid containing 'ghosts'. Appl Environ Microbiol 61:2180-2185

Submitted: February 7, 2001, Accepted: July 3, 2001

Proofs received from author(s): January 11, 2002 